$\mathbb{T}$ periodica polytechnica

Architecture

43/1(2012) $1-9$

doi:10.3311/PPar.7156

http://www.periodicapolytechnica.org/ar

Creative Commons Attribution (i)

RESEARCH ARTICLE

\section{Challenges of structural Decisions in contemporary architecture}

\author{
Zsuzsanna Fülöp
}

RECEIVED 2013-03-06

\section{Abstract}

Design in contemporary architecture has become increasingly exploratory in recent years. Digital architecture and the huge number of construction products allow a diverse range of complex forms to be created. Today, sustainability is a key factor in architecture, with architects continually looking for ways to reduce the use of energy and other natural resources, and then harvest and re-use those resources.

As a result of these new perspectives and tools, the architectural design process must become more conscious. Architects need to take into consideration the full complexity of available social, cultural, functional, economic, natural, structural, material and technological data, while providing control over the decisions of the design process. The Holistic Performance Based (HPB) [9] method and its approach to the design process could be a toolkit for choosing the most appropriate structural solutions. The essential part of the decision process is a properly modifiable Project-oriented Site-specific Database (PSD) [15], continuously fitted to the project, consisting of real, up to date and comparable data.

\section{Keywords}

Holistic Performance Based · Project-oriented Site-specific Database

\section{Acknowledgment}

This paper was supported by the Janos Bolyai Research Scholarship of the Hungarian Academy of Sciences.

\section{Main aspects of contemporary architecture}

Our current technology dictates that buildings not only serve as residences or offices etc. but must also be self-sustaining and in harmony with nature. Architects should impart their creative ideas into structures that fit into the environment and endure for many years, existing harmoniously with nature. The design of the building should take into account the cost and ecological impact over its entire lifetime, from extraction and processing of the building materials to construction, occupation and the eventual demolition of the building at the end of its useful life. In this context, important factors are running costs, energy efficiency, maintenance and durability of materials, pollution minimization, the energy embodied in the materials during their manufacture, and the building's potential for refurbishment or adaptive reuse.

Design plays a very important role in architecture, not just aesthetically, but technically. As technology evolves and software becomes more powerful, it enables architects to explore new possibilities. Architects visualize their designs throughout the process, exploring the shapes that make the structures and determining changes that need to be made.

Introducing 3D software into the architectural design process has allowed contemporary architects to explore new depths and push design boundaries. Models can be created in 3D and manufactured directly from the 3D data. Computer modelling programs rely on "sets of numbers stored in electromagnetic format". Digital architecture allows calculations that delimit architects and allow a diverse range of complex forms to be readily created through the use of computer algorithms.

\section{Structural decisions in contemporary architectural design}

The huge number of building industry information technology products (CAD etc.) gives architects the feeling that almost any geometrical shape may be physically realized. Consequentially, professionals envision increasingly unusual building types. Houses are more often than not too complicated and too expensive. This is true in the case of exclusive buildings as well as

\section{Zsuzsanna Fülöp}

Department of Building Constructions, Faculty of Architecture, Budapest University of Technology and Economics email: zsfulop@epsz.bme.hu 
simple family houses. The question is whether architecture is to create special houses at the border of structural possibilities, or are there other factors that should also be considered?

Digital architecture by computer modelling, programming, simulation and imaging, allows the creation of both virtual forms and physical structures. Architecture created digitally might not involve the use of actual materials (brick, stone, glass, and steel, wood etc.).

The Frank Gehry-designed Walt Disney Concert Hall in Los Angeles, California, opened on October 24, 2003, and consists of extremely complex and organic shapes that could be a metaphor for a sail with the wind behind it, or a school of swimming fish. It is a unique architectural achievement that could not have been realized without the use of 3D in the design process.

The building is composed of asymmetrical shapes that flow together to create a very harmonic whole. Looking at a complex design in its entirety sometimes makes it difficult to understand the basic forms or shapes. The surfaces look complex, but knowing they were generated from a simple box object makes them easier to understand. After breaking down all the shapes as sketches and integrating them into $3 \mathrm{D}$, we can start to visualize how to reconstruct a final model. It was converted to an editable poly with the vertices pulled into the desired shape. These shapes look quite complex, but in fact they were generated using a simple box primitive.

Through the use of a computer algorithm, the integration of all these deconstructed shapes into a final 3D model was relatively easy; however, there were some problems during the construction process resulting from the structural costs and performances.

The project was launched in 1987, with Frank Gehry delivering the completed designs in 1991. Construction of the underground parking garage began in 1992 and was completed in 1996. Additional funds were required since the construction cost of the final project far exceeded the original budget.

Plans were revised, and in a cost-saving move, the originally designed stone exterior was replaced with a less costly metal skin. The Founders Room and Children's Amphitheatre were designed with highly polished mirror-like panels; the reflective qualities of which were amplified by the concave sections of the Founders Room walls. Some residents of the neighbouring condominiums suffered glare caused by sunlight that was reflected off these surfaces and concentrated in a manner similar to a parabolic mirror. The resulting heat made some rooms of the nearby condominiums unbearably warm, caused the air-conditioning costs of these residents to skyrocket and created hot spots on adjacent sidewalks of as much as $140^{\circ} \mathrm{F}\left(60^{\circ} \mathrm{C}\right)$. There was also the increased risk of traffic accidents due to blinding sunlight reflected from the polished surfaces. After complaints from neighbouring buildings and residents, the owners asked Gehry Partners to come up with a solution. Their response was a computer analysis of the building's surfaces to identify the offending panels. In 2005, these were dulled by lightly sanding the panels to eliminate unwanted glare.

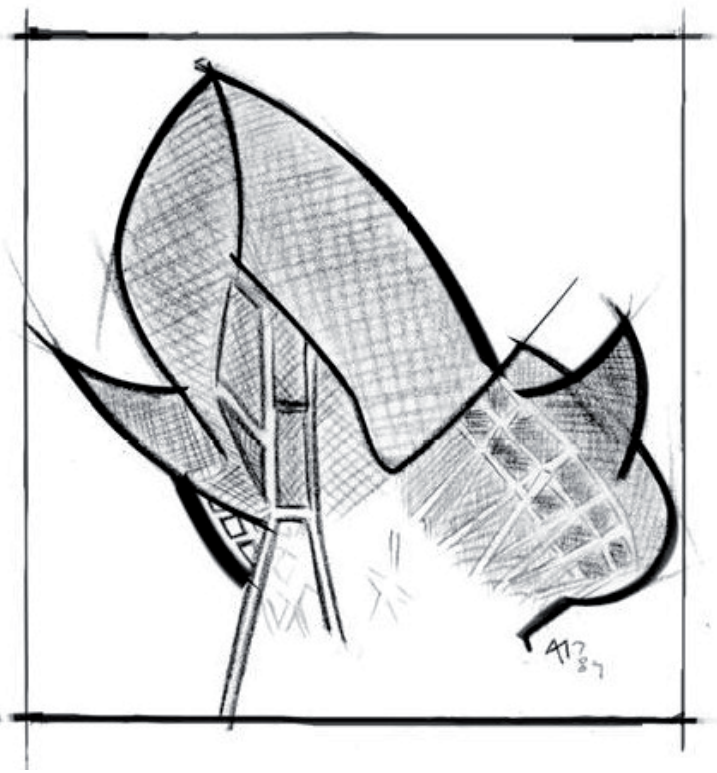

Fig. 1. Walt Disney Concert Hall - Inspiration [resource: wikipedia]

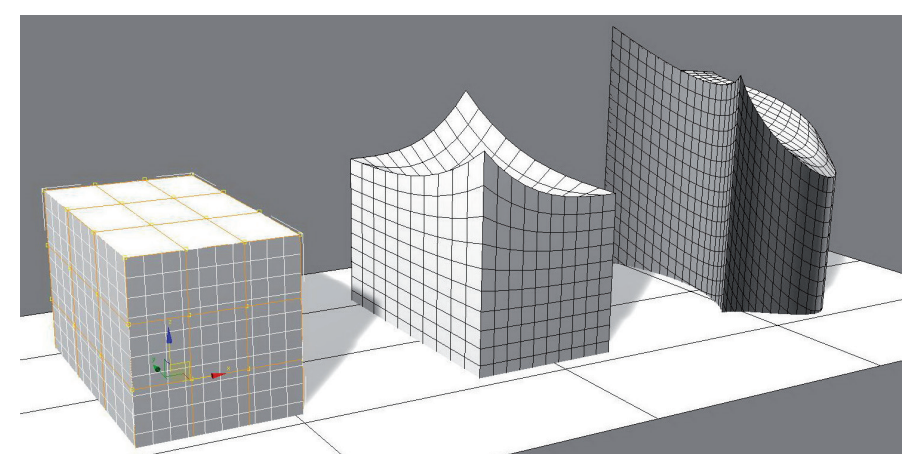

Fig. 2. Walt Disney Concert Hall - Broken shapes [resource: wikipedia]

This example effectively demonstrates the importance of performance based structural decisions. The understanding of connections between structural elements, their shapes, development and features have a much greater significance than in the past. When the architect envisions the concept of a building, he or she proposes not only form and function, but also the basic building materials. Each material has its special properties, from which the given requirements of installation must be derived. If the architect does not take into consideration the requirements of various building materials, the final solution will not be appropriate however much expert calculation, simulation and computer testing is performed.

Currently, there are thousands of new materials and structures sold all over the world, while the functions of our buildings have been changed and expanded. The question is how to take into consideration the whole complexity of important human attitudes, social, cultural and natural conditions, together with the integration of scientific results and computerization, and the challenge of the changing global, natural and economic situation during the architectural design process? How can we use the results of controlling the behaviours of forms, structures and materials more effectively? 


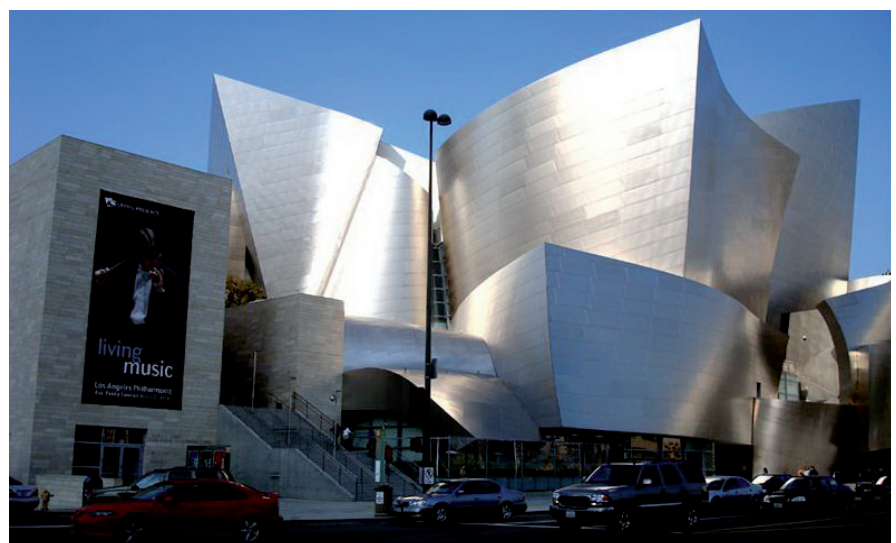

Fig. 3. Walt Disney Concert Hall - Model developing [resource: wikipedia]

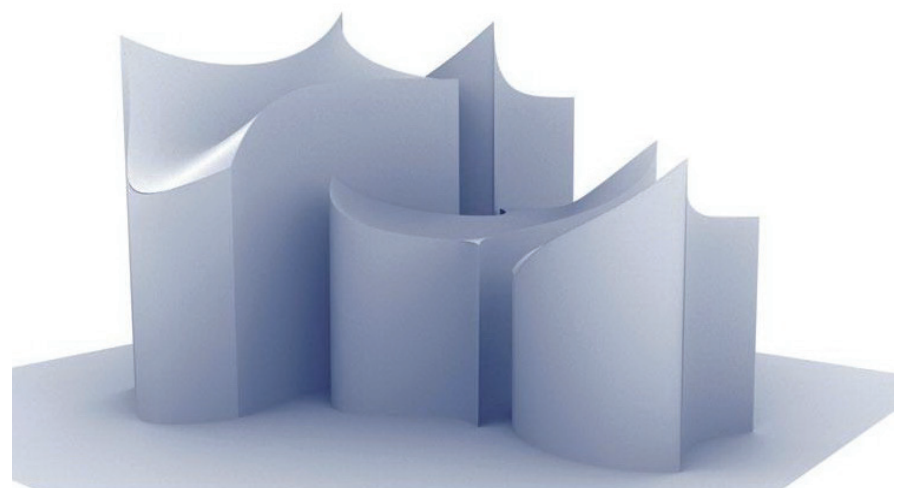

Fig. 4. Walt Disney Concert Hall - Executed building [resource: wikipedia]

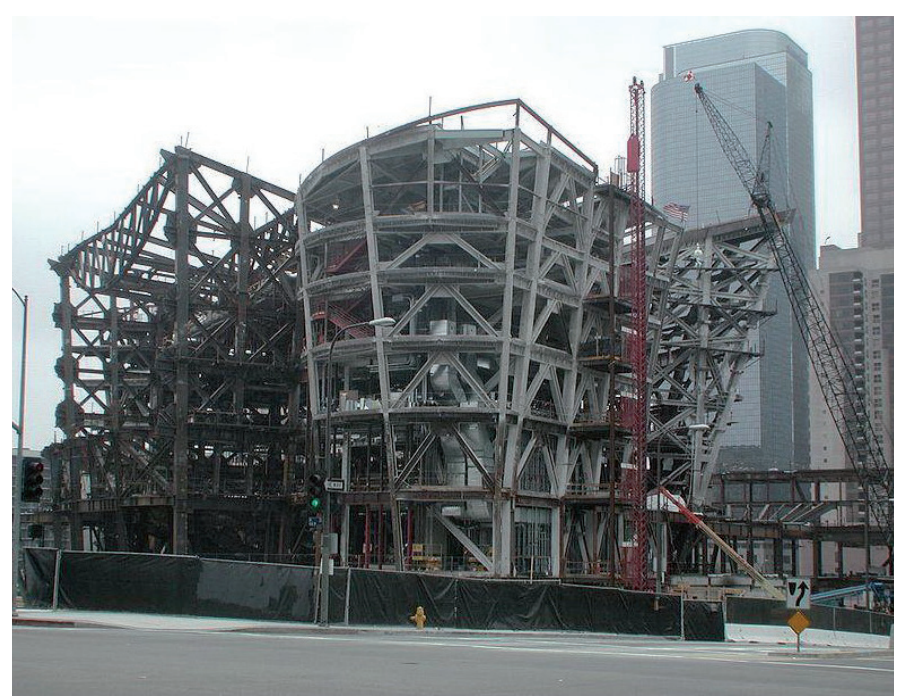

Fig. 5. Walt Disney Concert Hall - Load bearing construction [resource: wikipedia]

Material selection is a complex and delicate task determined by the immense number of building material options. Likewise, multiple factors (cultural, economic, ecological etc.) should be repeatedly considered by the architect when evaluating the various categories of building materials. As a result, these sets of factors or variables often present trade-offs that make the decision process even more complex.

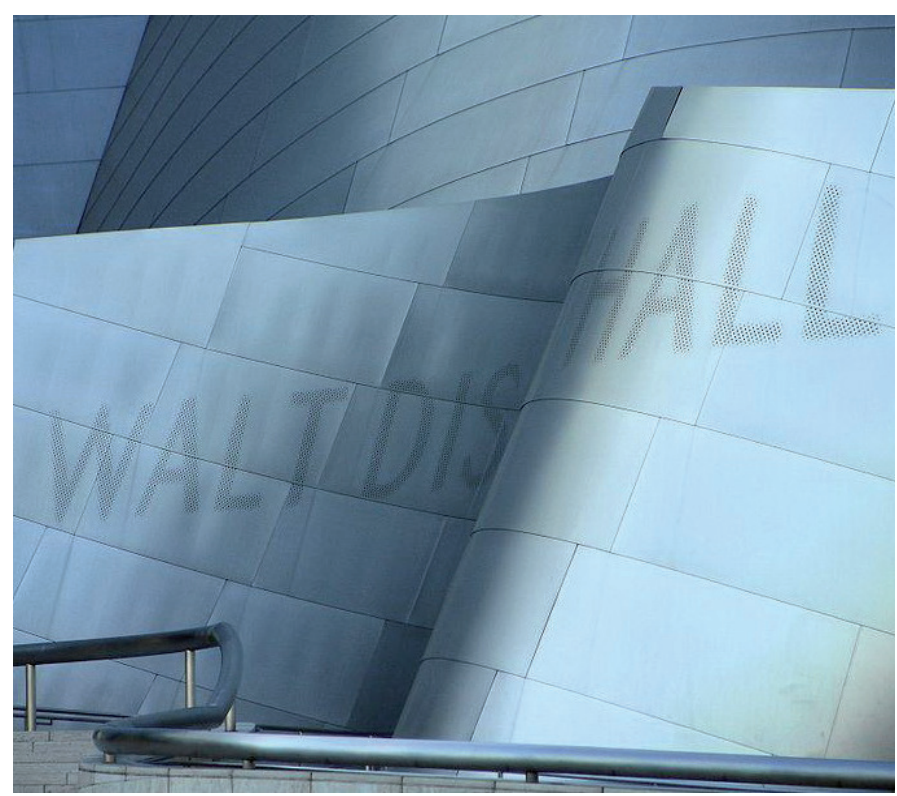

Fig. 6. Walt Disney Concert Hall - Metal covered elevation [resource: wikipedia]

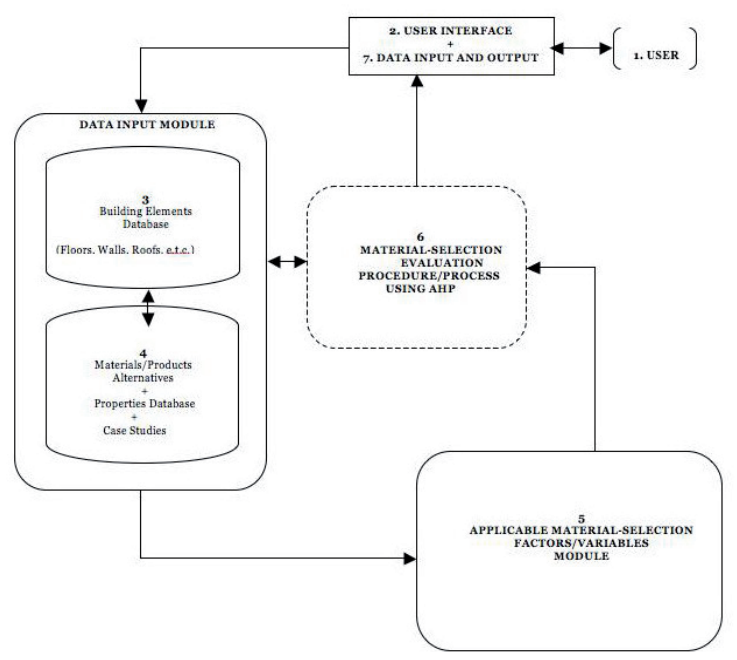

Fig. 7. Conceptual Model of the material selection toolkit [17]

The research of Ibuchim Ogunkah and Junli Yang [17] on green vernacular building material selection, holistically aims to develop a set of useful knowledge bases and structured 'selection' systems that will serve as the basis for evaluating such building materials in terms of their sustainability during the design process of a building project. A comparative analysis based on the results of the collected data shows that there are significant changes in building performance across countries, given their differences in building code restrictions in the use and mutual recognition of the performance of materials, geographical and environmental conditions. This research consists of a suggested toolkit for material selection.

\section{Database - the background of the design process}

Every building project involves the choice of building materials. Cautious consideration of contextual preconditions is 


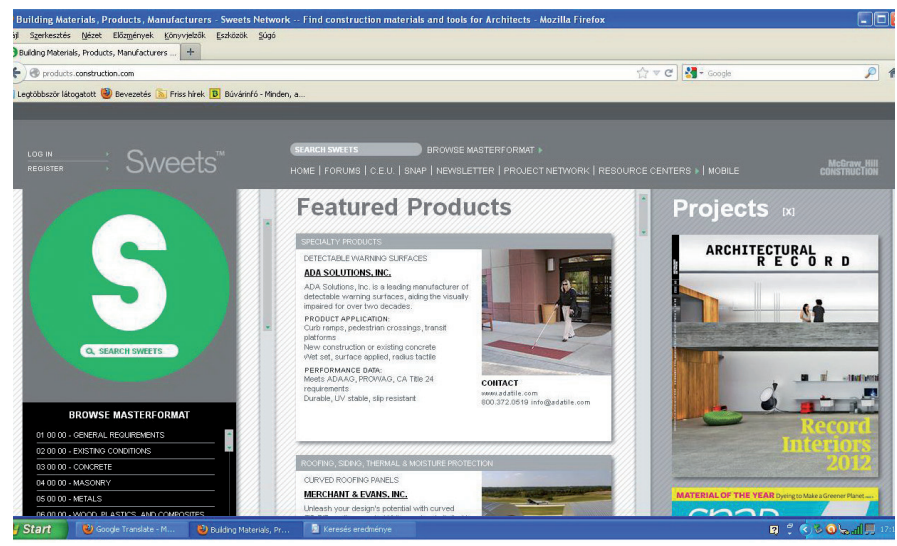

Fig. 8. Product oriented architectural database [resource: products. construction.com]

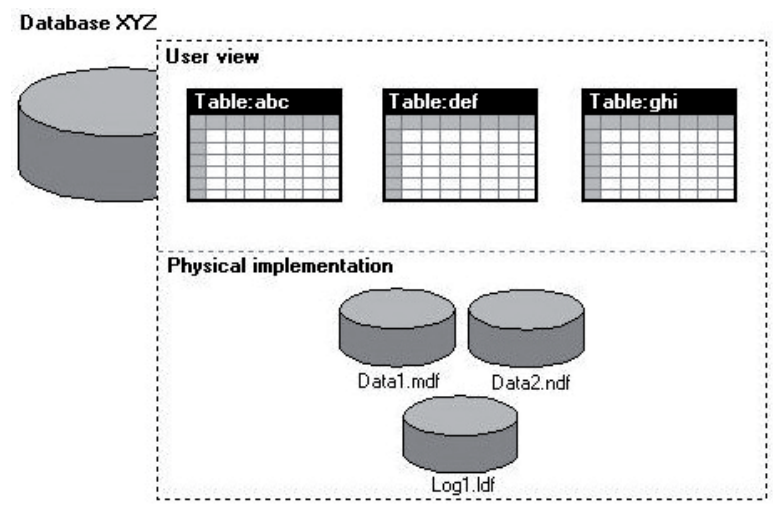

Fig. 9. Stakeholders' database

[resource: cramerz. Database Architecture]

crucial to selecting appropriate building materials or products. Selecting suitable building material options can bea very complex process, being influenced and determined by numerous preconditions, decisions, and considerations [17].

Computer aided design systems (CAD solutions) make the construction and drawing of building plans rapid and accurate. Projected physical dimensions and surfaces may be changed very easily. Architects, in theory, could have more control over the building design process, based on this freedom of shaping, modification through computer modelling, contemporary simulation and calculation methods.

The efficiency of the design process depends on the adequacy of the applied data. Architectural decisions can be correct only if they are based on a comprehensive, real, up to date and appropriate database, which in turn is always unique and local.

Database information can be labelled according to data content, type of data affiliated in a computer program and the targeted group of stakeholders etc.

The traditional database was an experience based system, every stakeholder added their knowledge and information to the project. Elements of the database were visible and accessible in documentations, maps, catalogues etc.

\begin{tabular}{llll} 
Layer & View & Data (What) & Stakeholder \\
\hline 1 & Scope/Contextual & $\begin{array}{l}\text { List of things and } \\
\text { architectural } \\
\text { standards } \\
\text { to the business }\end{array}$ & Planner \\
\hline 2 & $\begin{array}{l}\text { Business Model/ } \\
\text { Conceptual }\end{array}$ & $\begin{array}{l}\text { Semantic model or } \\
\text { Conceptual/Enterprise } \\
\text { Data Model }\end{array}$ & Owner \\
\hline 3 & $\begin{array}{l}\text { System Model/ } \\
\text { Logical }\end{array}$ & $\begin{array}{l}\text { Enterprise/Logical } \\
\text { Data Model }\end{array}$ & Designer \\
\hline 4 & $\begin{array}{l}\text { Technology } \\
\text { Model/Physical }\end{array}$ & Physical Data Model & Builder \\
\hline 5 & $\begin{array}{l}\text { Detailed } \\
\text { Representations }\end{array}$ & Actual databases & Subcontractor \\
\hline
\end{tabular}

Fig. 10. CAD system database [resource: cramerz. Database Architecture]

As part of globalization, the building elements - materials and components - are arranged on the internet through some product oriented building element basis.

Clients may compare and select from structures or materials as they compile its specification. The elements covered include external walls, internal walls and partitions, roofs, ground floors, upper floors, floor finishes, windows, insulation and landscaping. These extensive catalogues are continually being updated with specifications covering most common products.

Architects have difficulties in choosing the best product from these databases because of the huge number of elements (one database division - e.g. thermal and moisture protection - could contain more than 10000 enterprises each with their own products!). To compare the data of different products is sometimes problematic because of the different backgrounds (standards, measurement methods, units etc.). In these databases, there is no information about application of structures and materials according to the local climatic conditions.

The computer database programs through Database Management Systems (DBMS) are a ubiquitous and critical component of modern computing. Given these various options, a typical DBMS needs to be compatible with many different connectivity protocols used by various client drivers.

The computer database architecture is the set of specifications, rules and processes that dictate how data is stored in a database and how it is accessed by components of a system. It includes data types, relationships and naming conventions. The database architecture describes the organization of all database objects and how they work together. It affects integrity, reliability, scalability, and performance. The database architecture involves anything that defines the nature of the data, the structure of the data, or how the data flows. The database information can be labelled according to data content, the type of data affiliated in a computer program and the targeted group of stakeholders etc. This knowledge is implemented during the selection, designing and inspection of materials and construction components; in the drawing up of construction details; in the analysis and design of 


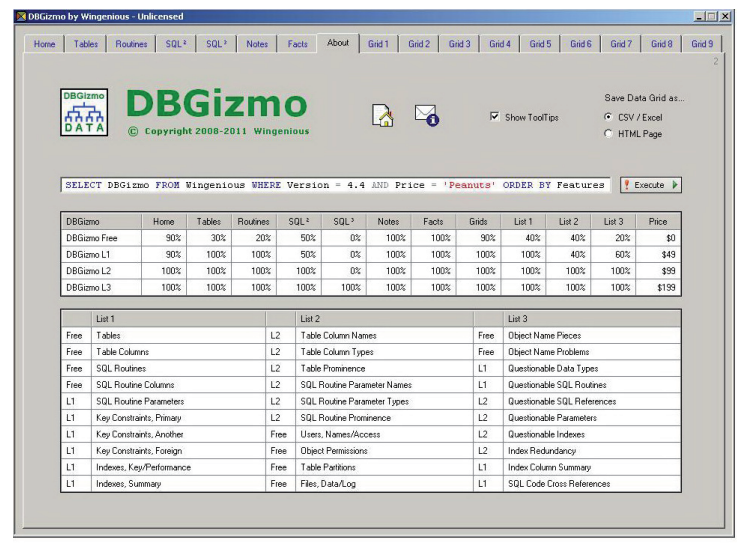

Fig. 11. Database Dialogue Box [resource: cramerz. Database Architecture]

the technological aspects of the execution; and in the process of preserving, renovating and upgrading existing buildings.

The structure of a computer databases is hidden; the architect can use it through the dialogue boxes or windows. The storage and access of these data depends on the computer program, so these are available only for those clients who have the appropriate software. These databases require a high level awareness of applied parameters.

Sometimes this method results in reductionism replacing the holistic approach. (In science, reductionism states that a complex system can be explained by reduction to its fundamental parts). This could be problematic because of the interaction between the environmental impacts and material properties.

This seems to suggest that there is a need to develop a systematic material selection system that will enable architects identify and prioritize the relevant criteria. In this case, they would be able to effectively and accurately evaluate the tradeoffs between technical, environmental, economic and performance issues during the material evaluation and selection processes. Therefore, to enable a structured and more comprehensive approach in the design-decision making process, in order to facilitate the process of comparing and identifying the best material option(s) across different categories, it is important that the design-decision maker (architect, designer or specifier) takes into account several material-selection factors or variables.

Architects need to take into consideration the whole complexity of available social, economic and natural data while providing control on the decisions of the design process. This may only be achieved through the use of a properly modifiable database, continuously fitted to the project and consisting of real, up to date and comparable data.

In the Project Oriented Site-Specific Database (PSD) system, the compilation of information - according to the project and site - starts at the beginning of the design process, with the collection of the basic data of social, cultural, functional, natural, structural, material, economic and technological information.

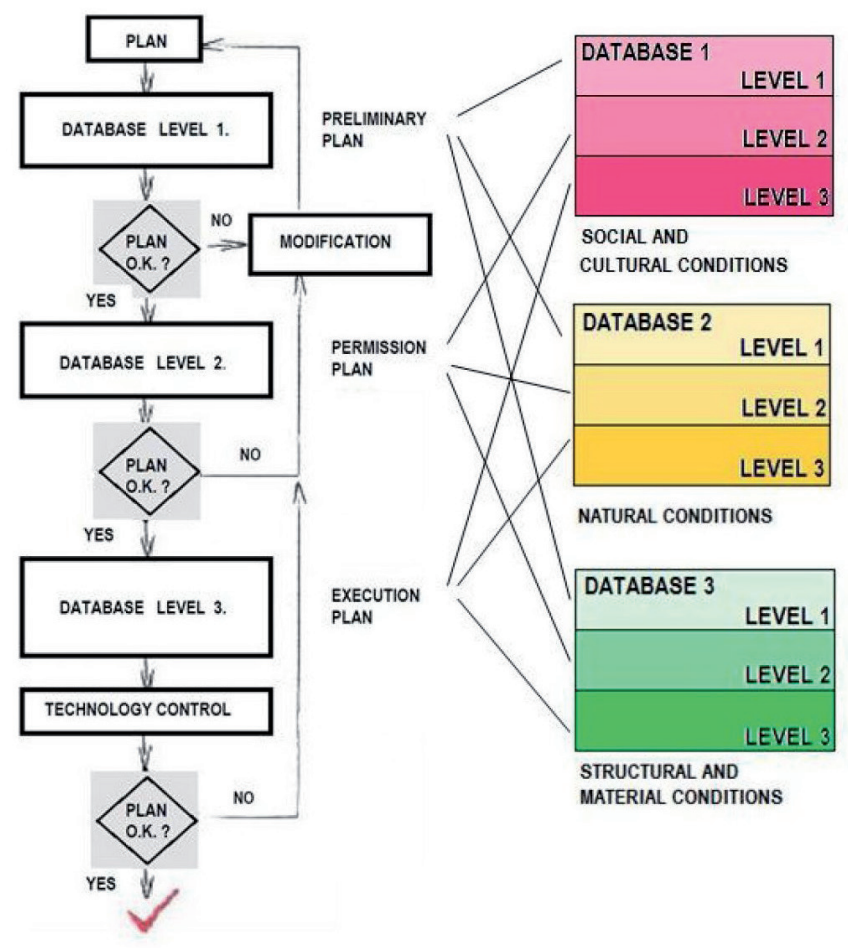

Fig. 12. Project oriented architectural database [15]

In this way, the first architectural and structural decisions can be made through the evaluation of real parameters and the complexity of the measurement will be more secure. The applied systemized parameters will be controlled and consciously selected. Each data type must be evaluated from the very first step of the project.

\section{Database aspects of energy efficient architecture}

Widespread awareness of climate change, together with the technical requirements arising from new regulations such as the Directive on Energy Performance of Buildings, has triggered professional demands for architects with advanced skills in sustainable design and energy efficiency.

Buildings account for $40 \%$ of total energy consumption in the European Union. This expanding sector will inevitably increase its energy consumption as stated in "Directive 2010/31/EU of the European Parliament and of the Council of 19 May 2010 on the energy performance of buildings". Therefore, the reduction in energy consumption and the use of energy from renewable sources in the buildings sector constitute the important measures needed to reduce the EU's energy dependency and greenhouse gas emissions.

Measures to further improve the energy performance of buildings should take into account climatic and local conditions as well as the indoor climate environment and cost-effectiveness. These measures should not affect other requirements concerning buildings such as accessibility, safety and the intended use of the building.

Each building location is unique, not just culturally and philosophically, but in terms of 'energy-environment': the possible energy gains and losses resulting from the unique locality 


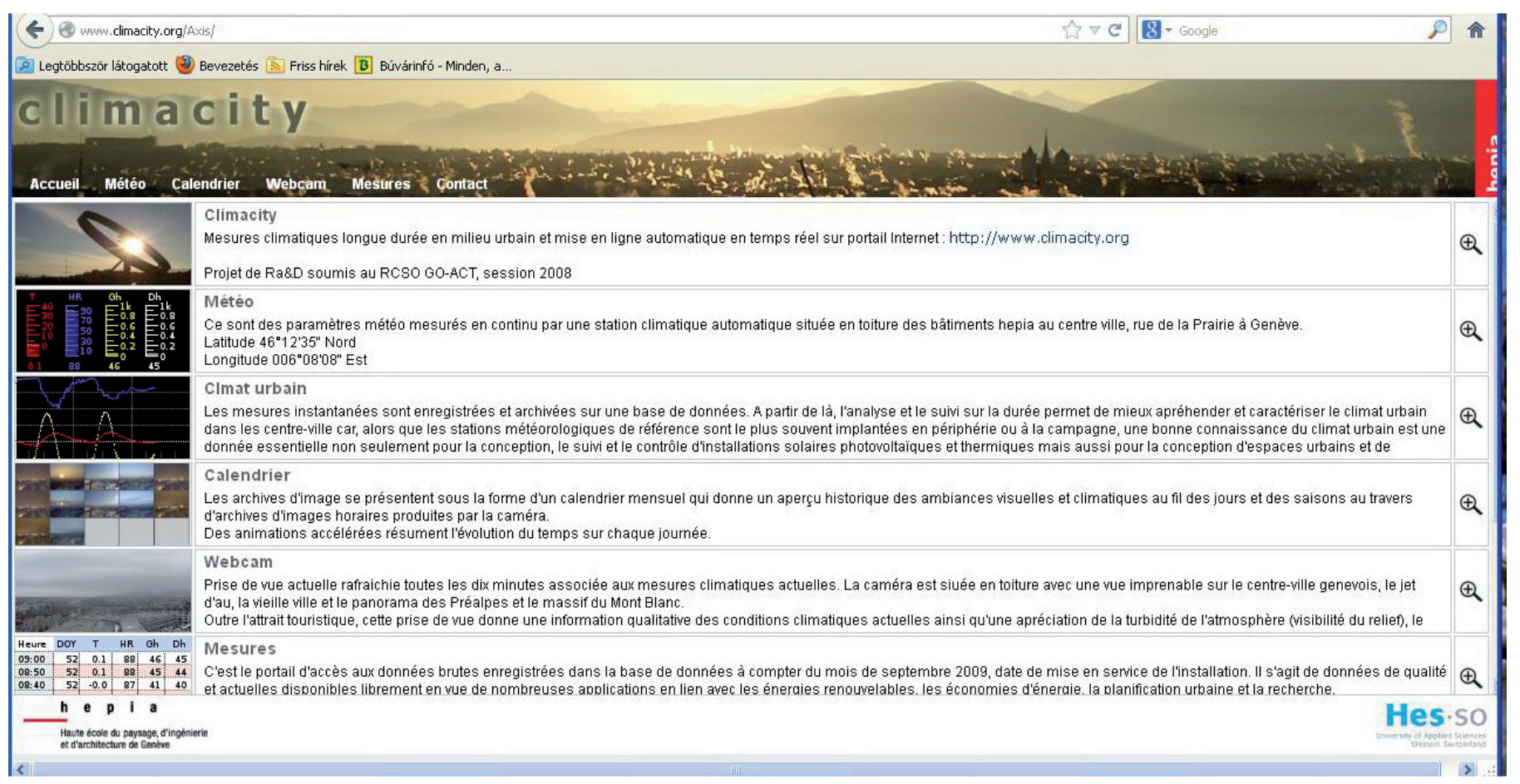

Fig. 13. Climate data for architectural database (resource: climacity.org)

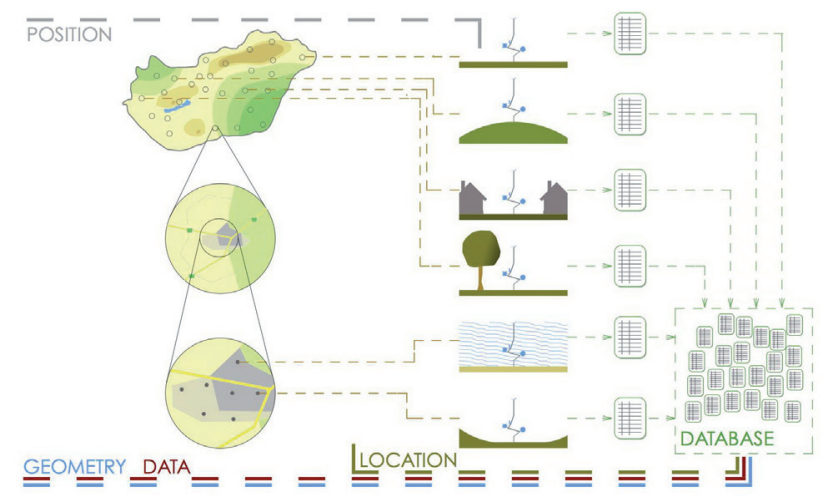

Fig. 14. Climate data for architectural database (resource: climacity.org)

(climate, terrain, shading, etc.). The online climate information database is a crucial factor of truly energy-efficient architectural design.

In order to detect and demonstrate the special 'energy-environment', architects of Budapest University of Technology and Economics developed a device, a database-system and software that can be used by architects in the earliest design phase.

The practical examples confirm the crucial impact of local climate, which can badly damage the built structures and at the same time significantly decrease their thermal insulation capacity.

To achieve the long term appropriate structural solution and the same thermal insulation capacity throughout the whole life of the building, we should take into consideration the complex and interactive evaluation model. This consists of not only the specific information, but also helps recognize the coherencies.

A comparative analysis, based on the results of the collected

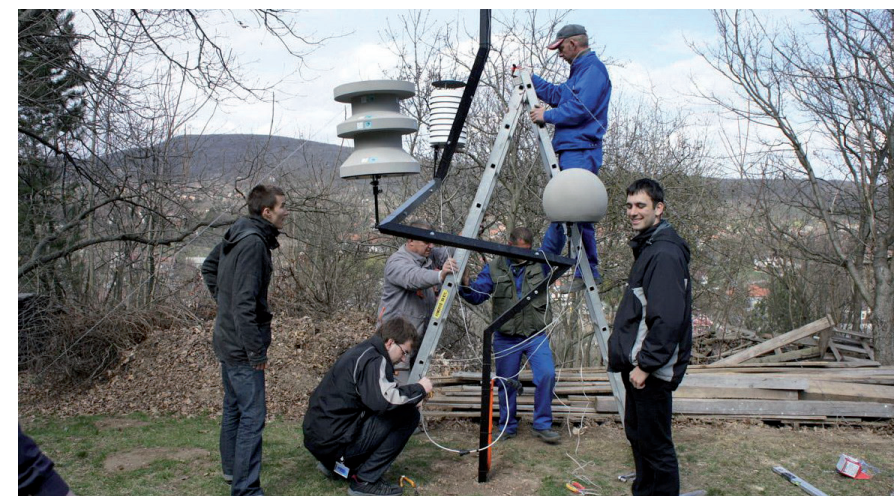

Fig. 15. Site specific database - Measurement of climate data [18]

data, shows that there are significant changes in building performance across different climate conditions and built in situations.

\section{Conclusion}

According to the new requirements, aspects and tools, the architectural design process must become more conscious. By rethinking the architectural design process as a coordinated set of stages and sub-stages, replacing the traditional experience-related process by a more rational and theory based approach, choices and solutions for specific design problems, traditionally taken based on experience or individual thinking, can now be taken founded in technical awareness and attentive to potential alternatives.

Analysis of the impacts, requirements and structural performances of each design stage can be the common ground of the dialogue between the architect and the experts according to the Performance Based Design method (PeBBu - CIB) In Performance-Based Building Design, evaluation of each design 


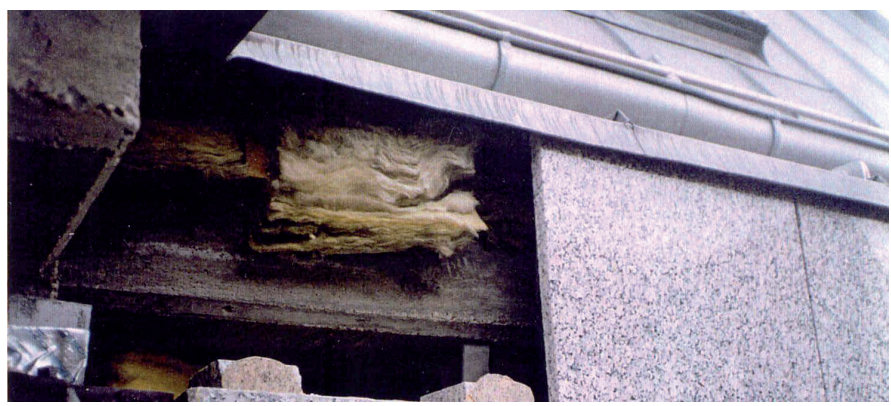

Fig. 16. Damaged thermal insulation on roof edge

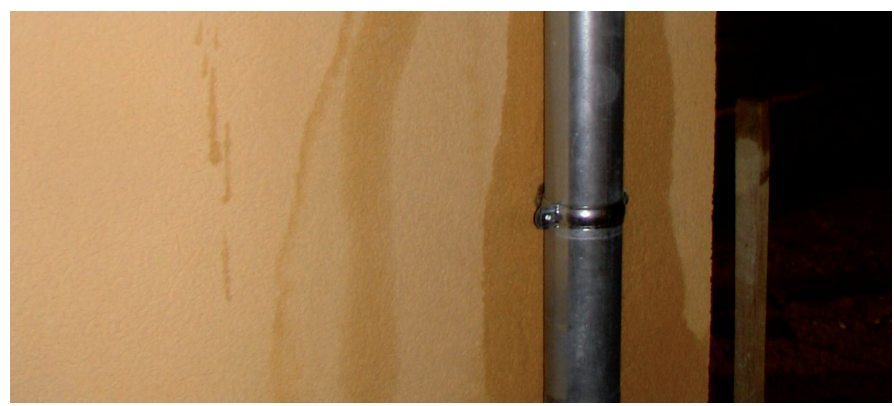

Fig. 17. Damaged thermal insulation on balcony

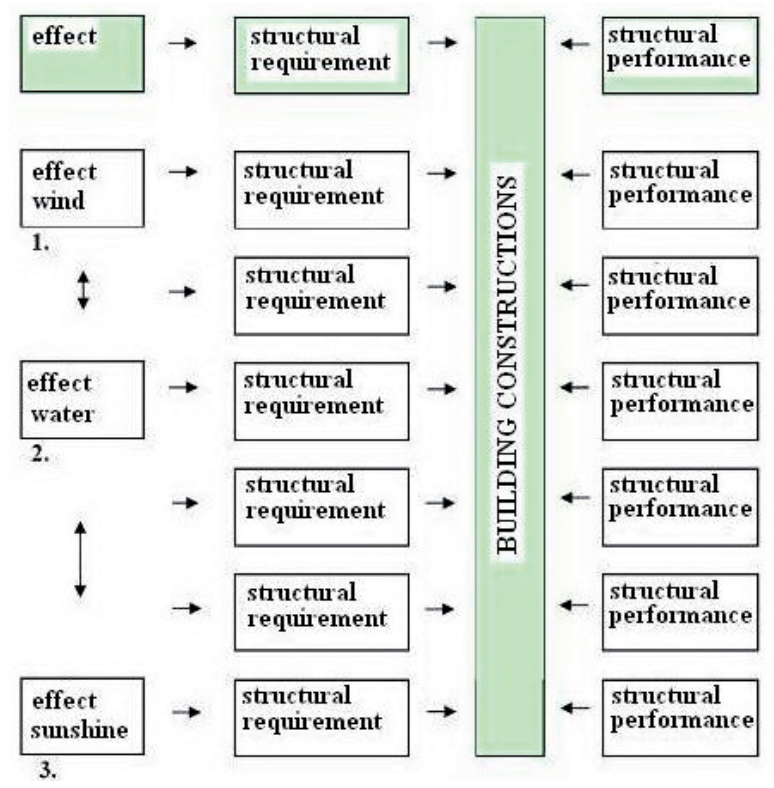

Fig. 19. Interactive structural evaluation model [9]

factor and aspect focuses on demand requirements and on the required performance in use. Performance requirements translate user requirements into more precise quantitative, measurable and technical terms, usually for a specific purpose.

Preventive and remedial measures and decisions should always be evaluated in the context of the whole (holistic approach). The Holistic Performance Based (HPB) [9] design process provides an awareness of the whole complexity of technical knowledge for architects. Architects will be able to develop a professional work, based on the data and calculations of specialists, international recommendations and techni-

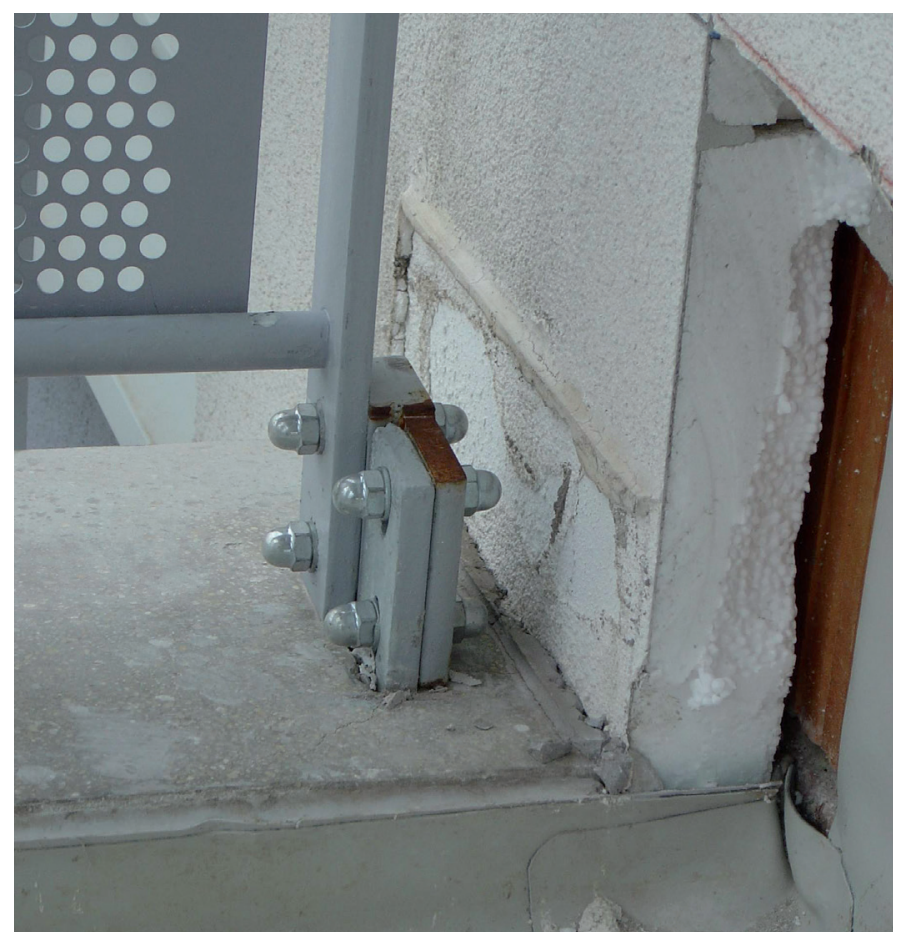

Fig. 18. Damaged thermal insulation on elevation

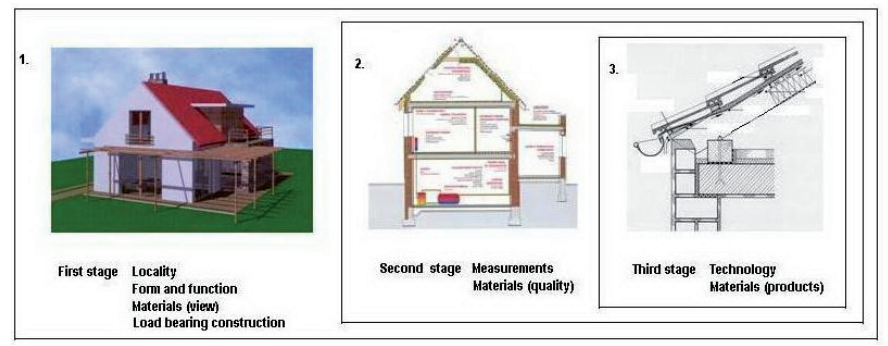

Fig. 20. Design stages [9]

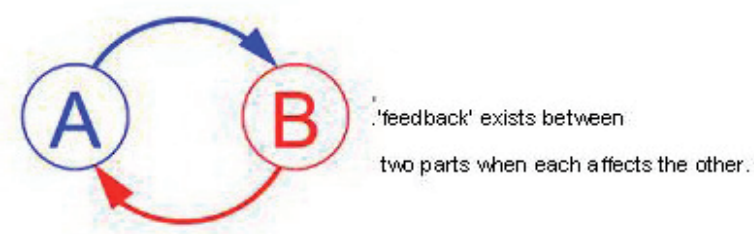

Fig. 21. Scheme of feedback system

cal guidelines. In this way, architects will be able to compare solutions and develop a self-critical evaluation, regarding their ethical and technological appetencies.

In such a design process, the architect can return to the earlier stages and improve on the previous decisions. Through this "feedback" mechanism on the effects, requirements and structural performances of each design stage, architects can develop the most appropriate solutions.

The designers in their practice conclude the design process, while they finally choose a specific design form, technique and materials. 
The content of the design stages does not depend on the design tools (e.g. manual or digital); however, the connected real and complex database is an essential factor.

Complex architectural measurement should always take into consideration the whole building (holistic approach), and each existing requirement evaluated based on the real environmental, social, economic, material effects (impacts), requirements and performances database from the very first step of the design process.
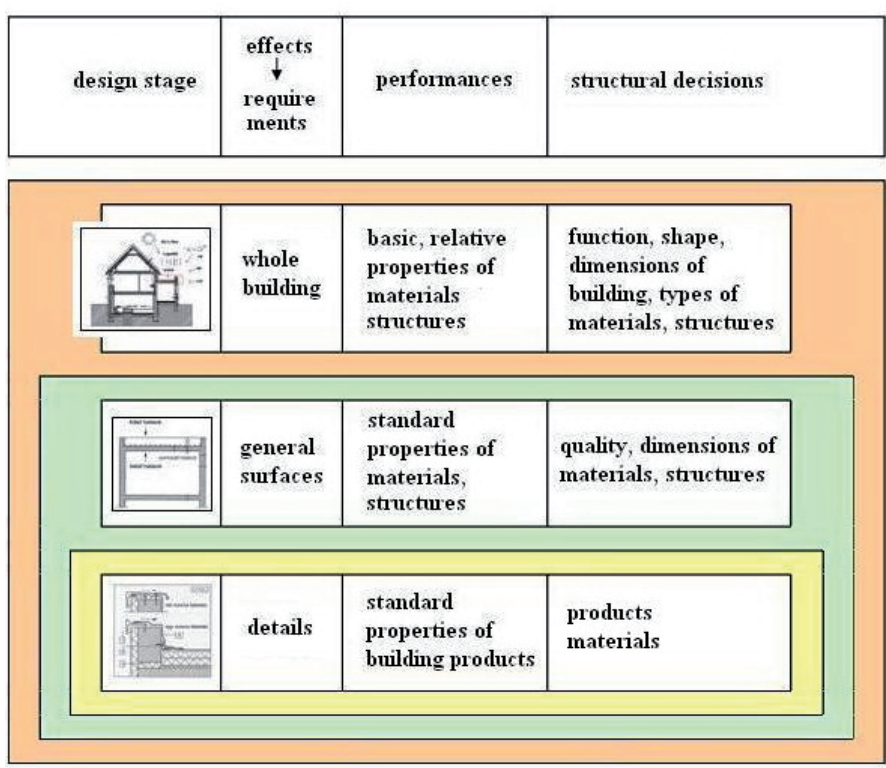

Fig. 22. Performance based holistic matrix of architectural design process [9]

\section{References and Notes}

1 Ashby M F, Johnson K, Materials and Design: The Art and Science of Material Selection in Product Design, Butterworth-Heinemann: Oxford, UK and Boston, NJ, USA, 2002.

2 Becker R, Foliente G, Performance Based International State of the art, PeBBu 2nd International SotA Report, CIBdf, Rotterdam, 2005

3 Cagan, J, Vogel C M, Creating Breakthrough Products, Prentice Hall PTR: Upper Saddle River, NJ, USA, 2002

4 Chan J W K, Tong T K L, Multi-criteria material selections and end-of-life product strategy: Grey relational analysis approach. Mater. Des. 2007, 28, pp. 1539-1546.

5 Chen S-J, Hwang C-L, Fu Multiple Attribute Decision Making, Springer-Verlag: Berlin, Germany, 1992.

6 Chueh T Y, Kao D T, The moderating effects of consumer perception to the impacts of country-of-design on perceived quality, J. Am. Acad. Bus. 2004, pp. 70-74.

7 Fernandez J E, Material Architecture: Emergent Materials for Innovative Buildings and Ecological Construction, Architectural Press: Amsterdam, The Netherlands and Boston, MA, USA, 2006.

8 Fülöp Zs, "Holistic System of Structural Education-Practice of Interdisciplinarity" (pages 471-479) New Aspects of Interdisciplinarity in Contemporary Construction Teaching, School of Architecture, University IUAV Venice, Italy, Printed by Charis Ltd, Thessaloniki, Greece 2006. ISBN 2-930301-31-7

9 Fülöp Zs, "Épületszerkezetek teljesitmény elvü, holisztikus szemléletü tervezése" PhD doktori értekezés BME Építészmérnöki Kar Épületszerkezettani Tanszék Csonka Pál Doktori Iskola 2007. - Zsuzsanna Fülöp: Holistic Performance Based Design of Building Constructions Ph.D dissertation Budapest University of Technology and Economics Faculty of Architecture Department Of Building Construction, Csonka Pál Doctoral School, Budapest, 2007.

10 Fülöp Zs, "Performance Based Architectural Design Method" (pages 141-149) Emerging - Possibilities of Testing and Simulation Methods and Techniques in Contemporary Construction Teaching, Faculté Polytechnique de Mons, Belgium, Printed by Charis Ltd, Thessaloniki Greece 2008. ISBN 2-930301-34-1

11 Fülöp Zs, "Sustainable Environmental Design - Responsibility of

Architects" (pages 427-440) Architectural Design and Construction Education - experimentation towards integration, Faculty of Architecture, University of Genoa, Italy, Printed by Art of Text SA, Thessaloniki, Greece, 2009. ISBN 978-2-930301-42-6

12 Fülöp Zs, Épületszerkezetek teljesitmény elvü tervezése Magyar Építőipar. 6. szám, pp. 208-209 oldal, Magyar Építőipar Kiadó Kft., Budapest, 2010 HU ISSN 0025-0074

13 Fülöp Zs, ,Energiatudatos épületek” Építés Spektrum, X. évfolyam 2. szám 6-9. oldal, Spektrum Lap- és Könyvkiadó Kft., Budapest, 2011. ISSN 1587-8724

14 Fülöp Zs, "Holistic Integrated Approach of Architectural Education \& Practice" (pages 655 -671) Rethinking the Human in TechnologyDriven Architecture, Technical University of Crete, Faculty of Architecture, Greece, Printed by Charis Ltd, Thessaloniki, Greece 2012. ISBN 978-2-930301-53-2

15 Fülöp Zs, "Project Oriented Database of Architecture" (pages 347-356) Scaleless - Seamless Performing a Less Fragmented Architectural Education and Practice, Münster School of Architecture, Germany, Printed by Charis Ltd, Thessaloniki, Greece 2012. ISBN 978-2-930301-58-7

16 Gibson E J, Working with the Performance Approach in Building, CIB Report Publication n.64, Rotterdam, 198223.GROSS J.G., Developments in the application of the performance concept in building, Proceedings of the 3rd symposium of CIB-ASTM-ISO-RILEM, National Building Research Institute, Israel, 1996

17 Ibuchim Ogunkah, Junli Yang, Investigating Factors Affecting Material Selection: The Impacts on Green Vernacular Building Materials in the Design-Decision Making Process, Buildings, 2012, 2, pp. 1-32, DOI 10.3390/buildings2010001 ISSN 2075-5309 www.mdpi.com/journal/buildings/

18 Perényi DLA, Kolossa J DLA, Hild Gy DLA, Energy Efficient Site Specific Planning Environmental Database of Local Architecture Scaleless - Seamless: Performing a Less Fragmented Architectural Education and Practice, Münster School of Architecture, Germany, Printed by Charis Ltd, Thessaloniki, Greece 2012. ISBN 978-2930301-58-7 
19 Saaty T L, Decision Making in Economic, Political, Social, and Technological Environments with the Analytic Hierarchy Process, RWA Publications: Pittsburgh, PA, USA, 1994.

20 Saaty T L, The Analytic Hierarchy Process, McGraw-Hill: New York, NY, USA, 1980

21 Van Kesteren I E H, Stappers P J, Kandachar P V, Representing Product Personality in Relation to Materials in a Product Design Problem. In Proceedings of the 1st Nordic Design Research Conference, Copenhagen, Denmark, 29-31 May 2005.

22 Wastiels L, Wouters I, Material Considerations in Architectural Design: A Study of the Aspects Identified by Architects for Selecting Materials. In "Proceedings of the Undisciplined!" Design Research Society Conference, 2008, Sheffield Hallam University, Sheffield, UK, 16-19 July 2008.

\section{Regulatory References}

24 ISO 6240: 1980, Performance standards in building - Contents and presentation

25 ISO 6241: 1984, Performance standards in building - Principles for their preparation and factors to be considered

26 ISO 6242: 1992, Building construction - Expression of user's requirements - Part 1: Thermal requirements

27 ISO 6242: 1992, Building construction - Expression of user's requirements - Part 2: Air purity requirements

28 ISO 6242: 1992, Building construction - Expression of user's requirements - Part 3: Acoustical requirements

29 ISO 6243: 1997, Climatic data for building design: proposed systems of symbols

30 ISO 7162: 1992, Performance standards in building - Contents and format of standards for evaluation of performance

31 ISO 9699: 1994, Performance standards in building - Check list for briefing - Contents of brief for building design

32 ISO 9836: 1992, Performance standards in building - Definition and calculation of area and space indicators

\section{External Links}

38 BRE - Building Research Establishment

39 CIB - International Council for Research and Innovation in Building and Construction

40 CSTB - Centre Scientifique et Technique du Bâtiment

41 IAI - International Alliance for Interoperability
23 Wastiels L, Wouters I, Lindekens J, Material knowledge for Design: The architect's vocabulary, Emerging trends in Design Research. In Proceedings of the International Association of Societies of Design Research (IASDR) Conference, Hong Kong, Hong Kong, 12-15 November 2007.

33 ISO 9000-00: 2000a, Quality Management system - Fundamentals and vocabulary

34 ISO 9001-00: 2000b, Quality Management system - Requirements

35 CEN (2002). EN 12152:2002 Curtain Walling - Air Permeability -Performance Requirements and Classification. CEN, European Commission for Standardization, Brussels.

36 CEN (2002 - 2007). Structural Eurocodes (EN 1990 - Eurocode: Basis of structural design. EN 1991 -Eurocode 1: Actions on structures. EN 1992 - Eurocode 2: Design of concrete structures. EN 1993 —Eurocode 3: Design of steel structures. EN 1994 - Eurocode 4: Design of composite steel and concrete structures. EN 1995 — Eurocode 5: Design of timber structures. EN 1996 - Eurocode 6: Design of masonry structures. EN 1997 - Eurocode 7: Geotechnical design. EN 1998 - Eurocode 8: Design of structures for earthquake resistance. EN 1999 - Eurocode 9: Design of aluminium structures). CEN, European Commission for Standardization, Brussels.

37 UNI 10838: 1999, Building. Terminology for users, performances, quality and building process

42 PeBBu Thematic Network

43 www.Climacity.org

44 http://en.wikipedia.org/wiki/Walt_Disney_Concert_Hall

45 http://www.cramerz.com/css Database Architecture

46 products.construction.com 